\title{
Pedagogical scenarios enriched with audiovisual technologies and their impact on the promotion of the learning skills of inmate students in Portugal
}

\author{
Sara Dias-Trindade \\ sara.trindade@uc.pt \\ University of Coimbra, Portugal \\ José António Moreira \\ jmoreira@uab.pt \\ Open University, Portugal
}

\begin{abstract}
Over the last decades and largely due to changes taking place in labour markets, there has been a pressing need to rethink pedagogical processes. Today, educational institutions face the challenge of not only having to create learning environments conducive to the acquisition of knowledge, but also scenarios suited to the development of learning skills. Our analysis will focus precisely on one of such scenarios and will determine its impact on the learning skills of twenty inmate students, based on the qualitative analysis of their perceptions and narratives and using the Pedagogical Model developed by Moreira (2017) for the design of e-learning activities focused on the "deconstruction" of moving images as a reference. The findings show that the design of the environment, based on this model and on the use of audiovisual technologies, can have very positive effects on inmate students' self-learning in the following dimensions: Active Learning, Initiative and Autonomy.
\end{abstract}

\section{Keywords}

Learning Skills; Audio-visual Technology; Inclusion; Education in Prisons 


\section{Introduction}

The European political context is advocating greater investments in adult learning/training to allow for the adaptation to the changing world and to the challenges imposed by globalisation. The EU Member States foresee that this adaptation will be achieved via the development of key competences for lifelong learning, for example, in communication, digital competences or social and civil competences (European Union, 2006).

Although not without criticism, this vision of skills-driven education is, to some extent, also in line with the universal values of equality, intercultural understanding, respect for cultural diversity and human rights advocated in international conferences on adult learning (Preece, 2011; UNESCO, 2010).

In order to move towards social justice, we need to respect equality and universal rights - as points of reference for social coexistence and democratic governance - without losing sight of the need to acknowledge differences and of the individual needs of the various social groups, in a fair distribution approach.

In fact, access to education and training has become a growing concern of the various international bodies. Moreover, there is a clear concern in respect of minority groups at risk of exclusion, such as the prison population, as can be seen from the Recommendations of the Council of Europe on the rules of European prisons (1989), and from the different studies that have concluded that the greater the access to education and training during detention, the lower the rate of repeat offences (Campos, 2015).

Access to education by the detainees should, therefore, involve not only the development of competences in areas that may be useful for their reintegration in community, but also digital proficiency, which has also been described by the European Commission as one of the most important competences for real social integration (European Commission, 2003, 2005), thus adapting their learning to labour market needs (Moreira et al., 2016).

This paper aims to promote the (social and digital) integration of prisoners based on a projected Lifelong Learning (LLL) programme for the development of learning skills related to the ability to learn and to initiative and autonomy in learning, targeted at the detainees of a Portuguese prison.

The concept of learning skills under analysis is a predictive variable of the academic relation associated with an attitude of openness to learning opportunities that draws on everyday experiences and with the ability to effectively use these formal and informal experiences. Therefore, engaging in learning is to call forth skills such as self-sufficiency, self-responsibility, selfconfidence in the pursuit of objectives and of active participation in various social contexts, all of the qualities that are necessary in all life situations (Nyhan, 1996).

We know that the ability to learn on your own is, today, an essential requirement for success. An autonomous individual is someone who knows how to identity learning needs and uses his or her personal resources effectively, using cognitive, social and creativity skills in a systematic and flexible way (Faria, Rurato \& Lima Santos, 2000; Lima Santos, Rurato \& Faria, 2000).

More than learning, learning to learn is an important means of making further progress, of enrichment and of personal and social well-being. This controlled and controlling dimension for promoting the ability to compete, cooperate and act will increasingly determine the individual and society, on account of the knowledge the individual has acquired, built and mobilised (Lima Santos, 
Rurato \& Faria, 2000; Veiga Simão \& Flores, 2006; Rurato, 2008).

In the current European context, "learning to learn" has actually been considered, in various official documents, a necessary key competence in the knowledge society, implying, on the one hand, that the individual is aware of his or her own learning method and needs, identifying the opportunities available, and, on the other hand, that he or she is able to remove the obstacles to successful learning ${ }^{1}$.

So, based on these assumptions, the motivations for creating and developing this problem are related to the idea that it is indeed important that conditions exist for prisoners to not only reconstruct their concept of citizenship, but also to acquire and develop new learning skills, to deal with different symbolic systems and to live surrounded by media, thus facilitating their return to the community after they have served their time (Recommendation no. R(89)12 of the Committee of Ministers of the Council of Europe). So, it is required to rethink education's aims and methodologies, based on a concept of literacy that is in continuous evolution, related to the competences required to read, understand and communicate (Aguaded-Gómez \& Pérez-Rodríguez, 2012; Gutiérrez \& Tyner, 2012).

Recently, there is a growing emphasis on the relevance of digital competence, considered one of the eight key competences for lifelong learning (European Parliament and the Council, 2006) and several initiatives have been launched in Europe aimed at promoting digital competence (Vuorikari et al., 2016; Carretero et al., 2017), namely in Portugal (Portugal INCoDe.2030).

The benefits of combining digital and media literacy and the extending approaches developed in the area of media education, over many years, to encompass digital media are highlighted by different authors, such as Buckingham (2009), as a strategy to overcome those risks and to reinforce a critical dimension of literacy. International institutions, such as UNESCO and EU, have also been promoting research and intervention in the area of digital and media literacy (EU, 2007; Wilson et al., 2011; UNESCO, 2013) and this international context has led to the development of this domain also in Portugal, where initiatives like the one from National Council of Education (2011) or Portugal INCoDe.2030 have started to take place.

Also relevant to the development of the present program are the studies carried out in Spain, that led to a definition of a set of dimensions (language, technology, production and dissemination processes, ideology and values, interaction processes, and the aesthetic dimension) that configure the concept of media literacy competences (Ferrés, 2007; Ferrés \& Piscitelli, 2012).

Moreover, in addition to being concerned with the promotion of digital and media literacy, our intention with this programme is to promote that aesthetic education for understanding visual culture that is capable of educating the eye and enable the emancipation of this individual (Hernandez, 2000).

Choosing this methodology that makes use of audiovisual technologies is clearly a commitment to develop an education for and with image, including the cinema in learning activities, because as Fresquet (2013) argues, with the cinema as a partner, education tends to become inspired and kindles the forgotten pedagogical practices of the magic of what learning is.

\footnotetext{
${ }^{1}$ Cf. Proposal for the Recommendation of the European Parliament and the Council on the key competences for lifelong learning /*COM/2005/0548 final-COD2005/0221
} 
In fact, while the cinema represents a huge potential for learning, this potential depends a lot on the pedagogical model and strategy used, on the knowledge of film language, and on the creativity of the teacher. One of the most important aspects to be explored by the teacher is the cinema experience itself. As highlighted in film studies, the film narrative is not simply appropriated in terms of perception, but is a dynamic text that pushes the spectator to an intellectual construction, discovering, extrapolating and organising the information in order to make it meaningful. The spectator acts at various levels: he or she understands, identifies, interprets, makes assumptions, fills gaps, builds relationships, and experiences feelings.

More than semantics, the film language requires pragmatics, an active construction of meaning based on competences anchored in experiences and knowledge, in a more or less shared culture that one assumes is conveyed by the educational system.

In short, our research aims to consider various possible scenarios and alternative designs of Lifelong Learning, studying the effect of Author's pedagogical model (2017) on the design of elearning activities based on the "deconstruction" of moving images, on the development of the learning skills of inmate students in the following dimensions: Active Learning, Initiative and Autonomy.

\section{The Lifelong Learning Programme: "Education for Citizenship. Intervention Pathways".}

The programme, which we have called Education for Citizenship - Pathways of Intervention - starts from the premise that The world is changing!! to issue the challenge of building a new citizenship that will enable the detained citizen to "control his or her destiny" and to jointly contribute, in an uplifting manner, to the collective destiny. A new citizenship that may help the prisoner to (re)build his or her personality and character. Having topics such as human rights and their universality, especially in respect of gender equality, sustainability and intercultural understanding, in a context of Lifelong Learning, this programme aims to effectively contribute to an education based on autonomy and solidarity, social and cultural pluralism, and on the values inherent to democratic societies. 


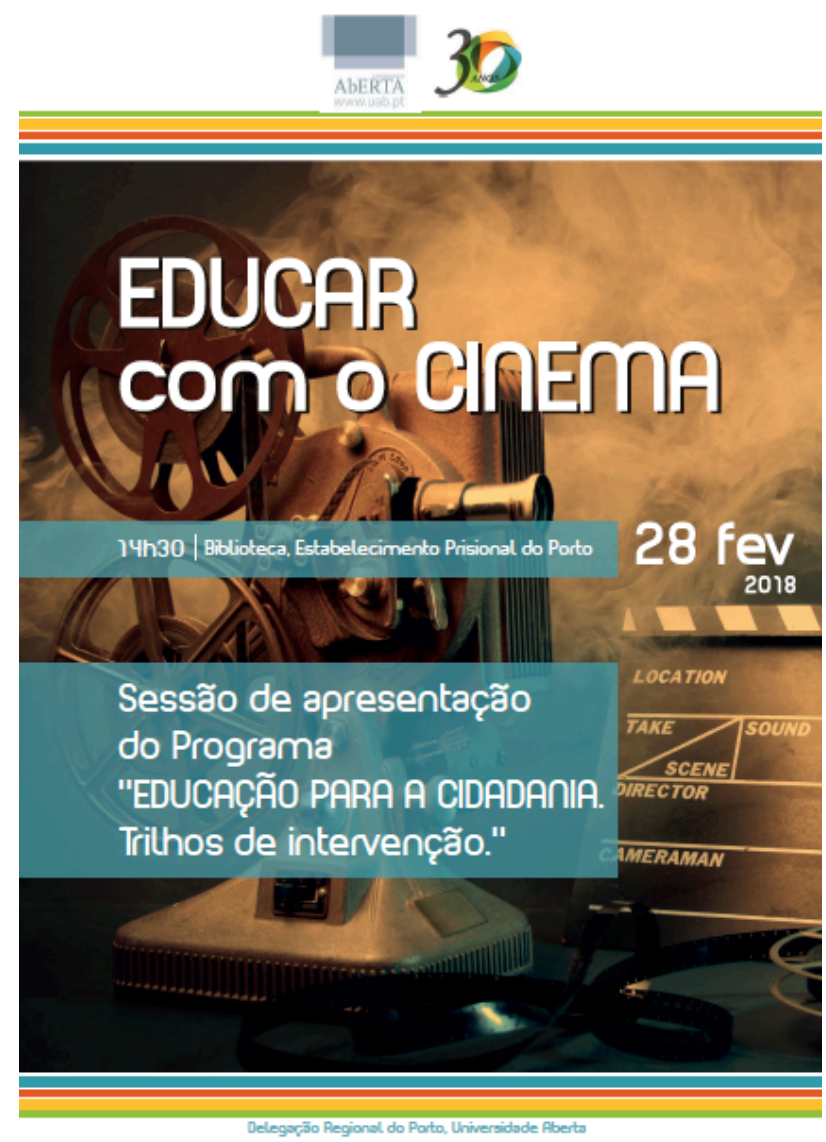

Figure. 1. Billboard of the programme Education for Citizenship. Intervention Pathways. Source: Authors.

\section{a. The Pedagogical Model. Parameters, Principles and Stages}

To implement the programme consisting of ten three-hour sessions, in a total of thirty hours training, we chose the flipped classroom methodology, based on the pedagogical model developed by Moreira (2017) for the design of e-learning activities focused on the "deconstruction" of moving images.

The guidelines and theory principles of this model are anchored in a learning that is Constructivist, Collaborative and based on Communities of Inquiry (Garrison \& Anderson, 2005) and that fosters reflection and critical thought, individual and social responsibility, and creative spirit; based on Interaction, it being understood as a principle underlying the pedagogical process, decisive not only for motivating, encouraging, and establishing mutual trust, but also for assessing the teachinglearning process and feedback; promoter of multiliteracy, this meaning the need for students to develop new skills in discursive analysis, to the point where they are able to convey and represent their world through models or new multimodal formats; of a Humanist Nature, where the student plays an active role by engaging in and committing to his or her learning process, and where the teacher acts as the moderator who accompanies, motivates, discusses, promoting and mediating a positive human interaction.

According to this model there are four stages in the development of this methodology. The first one is called Preparing or Planning and refers to the stage before the film is screened. The training team first chose and saw the film to see if it suited the desired objectives and its recipients 
(inmates). In the second stage, we prepared the activities to be developed and prepared the teaching aids to be used in the following stages. These aids include a script for an overall and functional first reading of the film and an observation chart, which was provided to the students before the film screening.

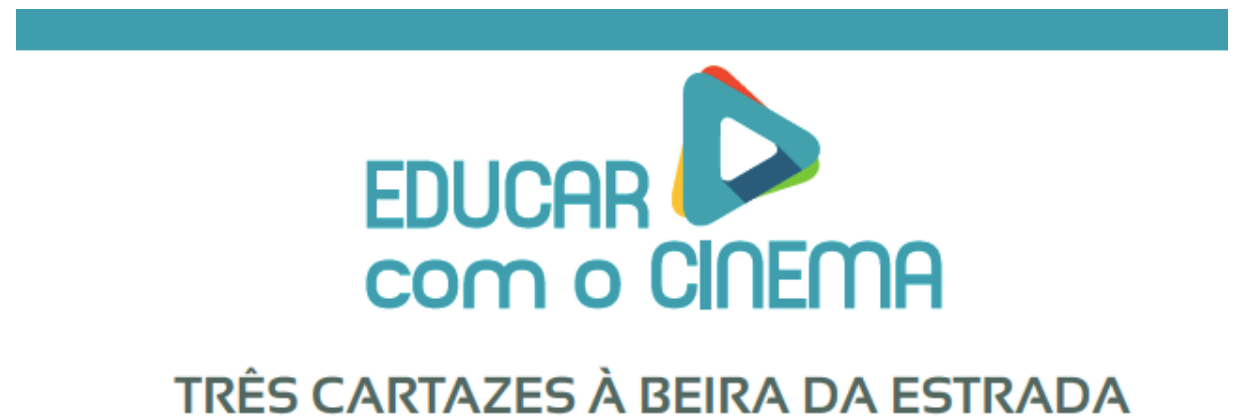

Realizador: MARTIN MCDONAGH, 2017, RU/EUA, 115min.
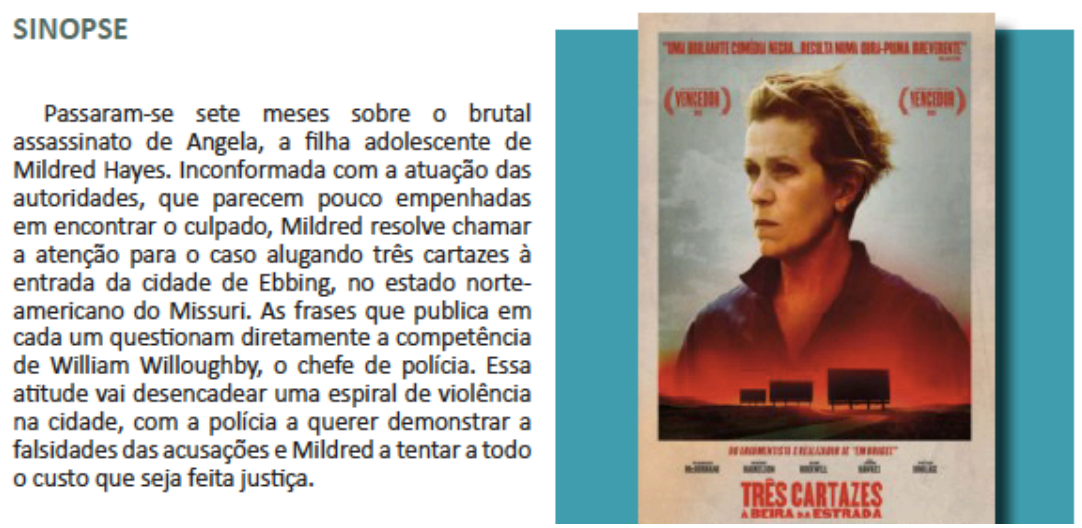

Figure. 2. Example of a film script - Session 4 Three Billboards Outside Ebbing (Martin McDonagh, 2017)

Source: Authors.

The second stage is called Film Screening, Reading and Analysis and refers to the viewing of the film. In this stage, students received the pedagogical support materials prepared in the first stage - the film script and the observation chart - to encourage them to actively see the film and assess its concepts.

The third stage is called Deconstruction of the Learning Object, Discussion and Reflection. In this stage, the teacher team presents the theory required to deconstruct the film and students are invited to discuss this theory and present their own thoughts on the film they have seen. Both the deconstruction and the discussion are the essence of the learning, because it is through them that the film is broken down into smaller units of analysis, the film excerpts, which are then discussed according to the knowledge of each student and to the information given in the observation chart. Finally, the fourth and final stage called Conclusion and Verification refers to this final summary of the activity, where teachers asked students to answer the questions on the script, therefore assessing the acquired knowledge. At this stage, teachers suggested other readings or films that address the same topic or other additional activities. 
The option to view audiovisual resources, films, is justified in this context because the cinema is more than an aesthetic object with specific features: it is a formative and educational language. The reading of this language, however, has often just scraped the surface and is subjective, detracting from its potential as a language of knowledge. Just like reading a book, to enjoy and read a film requires a minimum of information about the different aspects of its language and about the means used in its analysis. The filmic reading of the cinema language involves the deconstruction of the video and its subsequent reorganisation, giving it meanings not understood before, but also touching on complex and comprehensive knowledge on various analytical approaches and prior knowledge of its language. The cinema has indeed been used more and more as a didactic resource in educational contexts, because it has an inventive language and a narrative that covers almost endless topics and contents. Filmic reading education in this prison context means becoming aware, knowing how to make people aware, training through experimentation and involving the trainee-prisoner throughout the learning process.

\section{Methodology}

The study population consists of a group of twenty detainees of a Portuguese prison who are attending Tertiary Distance Education, and this training is in addition to the formal learning activities. We chose the Design Based Research (Wang \& Hannafin, 2005) since it aims to analyse educational problems in real contexts of teaching activity, with a view to solving significant and practical problems, combining theory and practice through the joint work of researchers and professionals who seek to understand, document, interpret and improve the educational practice. At the end of the training programme, the students had to complete a survey questionnaire and the content analysis method was used to analyse the data (Bardin, 1977; Vala, 1986).

In a first phase, we performed a vertical analysis of each questionnaire, while in the second phase we resorted to a horizontal or comparative analysis using the "constant comparative method" (Miles \& Huberman, 1994) to identify common and specific aspects of students' representations and perceptions.

Given the scope and purpose of this study, and the documentary analysis of some relevant norms in the context of the study, we were influenced by the Self-Learning Competence Scale (SLCS) developed by por Lima Santos et al. (2000) to build our instrument. As we can see in Table 1, the three dimensions that form the SLCS were those that we defined for our study.

\begin{tabular}{l|l}
\hline Elements \\
\hline $\begin{array}{l}\text { Active Learning or Accepting } \\
\text { Personal Responsibility for } \\
\text { Learning }\end{array}$ & $\begin{array}{l}\text { assessment of the perception of the ability to learn in } \\
\text { various situations and with others, and accepting the } \\
\text { personal responsibility for the learning process. }\end{array}$ \\
\hline $\begin{array}{l}\text { Initiative in Learning and } \\
\text { Orientation to Experience }\end{array}$ & $\begin{array}{l}\text { assessment of the orientation of learning to experiencing } \\
\text { concrete problems, as well as the initiative in the choice } \\
\text { of learning. }\end{array}$ \\
\hline Autonomy in Learning & $\begin{array}{l}\text { assessment of the autonomy in learning according to } \\
\text { personal needs. }\end{array}$ \\
\hline
\end{tabular}

Table 1. Self-Learning Competence Scale

Source: Authors. 


\section{Results}

Before we analyse the results, it is important to note that in the analysis of the resulting data we alternated betwen the two phases. In a first phase, we performed a vertical analysis of each of the questionnaires, and in the second phase we resorted to a horizontal or comparative analysis using the "constant comparative" (Miles \& Huberman, 1994) to identify common and specific aspects of students' representations and perceptions. A schematic diagram was prepared for this effect showing the respondents' answers, as an example of the relevance of some of their opinions. Note also that due to their assessment nature, records were marked as Positive Trend $(+)$, Negative Trend (-) and Hesitation/Uncertainty (+/-).

In the first dimension, Active Learning, on the ability of students to learn from this pedagogical strategy and their responsibility in the process of learning construction, records were classified as Present (+) and Absent (-). The first one, Present, received the most references - 19 records suggesting that students feel that the strategy developed, incorporated in the pedagogical model, enabled the learning of contents and the exchange of information, and was most important for them to be responsible for the learning construction; the second one, Absent, with one record only, shows that the model and audiovisual resources are unable to promote this learning.

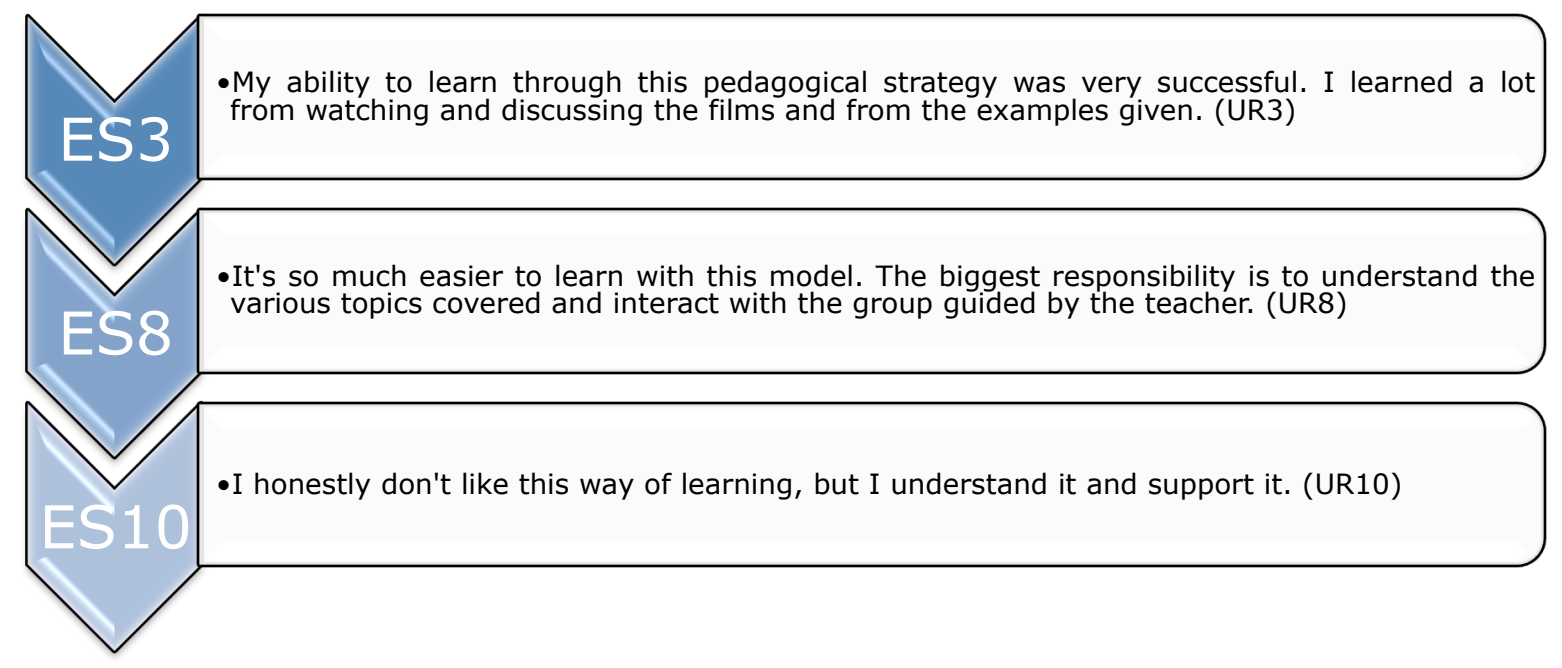

Figure. 3. Active Learning

Source: Authors.

As we can see, in the first record student -ES3- refers that the methodology was "a success", because it gave him the opportunity to learn with the support of audiovisual technologies, to reflect, to discuss various topics, and to acquire new knowledge.

In the second record (UR09), student -ES9-, in turn, emphasises that it's so much "easier to learn" with this pedagogical model, and on the other hand that he felt very responsible for the acquisition of knowledge, because the strategy always implied verbalising and "deconstructing" ideas taken during the screening. These testimonials suggest that the third stage of the model on the Deconstruction of the Learning Object, Discussion and Reflection, which according to the same respondent was the essence of the learning, was "successful". In the opinion of the majority of the students, the learning objects and audiovisual resources were deconstructed through the active participation of all community members, who engaged in intensive discussions and reflections on the ideas being debated, enabling them to build their own knowledge through successive cognitive 
conflicts.

Students -ES5-, -ES12-, -ES13- and -ES14- also remarked on the relevance of the strategy in the "growing" ability to learn.

ES5- "(...) My participation in this pedagogical activity was very positive, since it allowed me to address current issues of our society, listen to different opinions, present our views; so this helped me to grow and I feel that my responsibility for some of the topics that raised more public controversy increased throughout the entire learning process. (UR5)".

ES12- "For me this was a good learning strategy, as it has an obvious way of getting the message across, conveyed by the film. My responsibility was linked to the topics that interested me, so the more interesting they were, the greater my interaction. (UR12)

ES13- "The sessions were very productive, I was able to see and feel my perspective, share my opinion, and understand what the other participants felt while watching the same film. We don't see things the same way." (UR13)

ES14- "The pedagogical strategy used meant that we had to pay more attention to the entire activity, looking for points/focus of change throughout the screening of the film. In this sense, it increases the responsibility of the viewer and encourages his/her ability to learn." (UR14)

Although everyone was of the opinion that the strategy fostered each student's ability to learn and increase their responsibility in this learning process, students -ES5-, -ES12- and -ES13emphasised the importance of ensuing discussions, the exchange of different opinions, the interaction and the different perspectives that are built, while student -ES14- highlighted that he needed to be very focused during the screening of the film in order to discuss it later on.

It is interesting to note the emphasis given to the different perspectives being built after the screening of the film, because in fact this pedagogical model is also based on the Theory of Cognitive Flexibility, developed by Rand Spiro et al (Spiro et al., 1987; Spiro et al., 1988), which focuses on cases analysed or deconstructed according to multiple perspectives or topics, and considers two learning processes: the deconstruction process and thematic criss-crossing.

In this situation, the case is perceived as the audiovisual resource that involves two learning processes: a) the deconstruction process, when the discussion begins and perspectives emerge; and b) the process of thematic criss-crosses, when the perspective(s) given by the teacher allow students to access new references that will enable them to align the various viewpoints and have new perspectives on reality.

Note also the statement given by student -ES12-, who stresses the strong interaction with this methodology associated with the interest in the themes covered in the study, another clear principle of this model.

Finally, as we can see in the third record, one student -ES10- appears not to have liked this way of learning, although he understands and supports it, perhaps because he does not feel comfortable with the strategy of social involvement. 
As for the representations in the third dimension - Initiative in Learning- most participants refer that the environment has fostered individual initiative, the participation of the community members, particularly as regards learning and problem-solving.

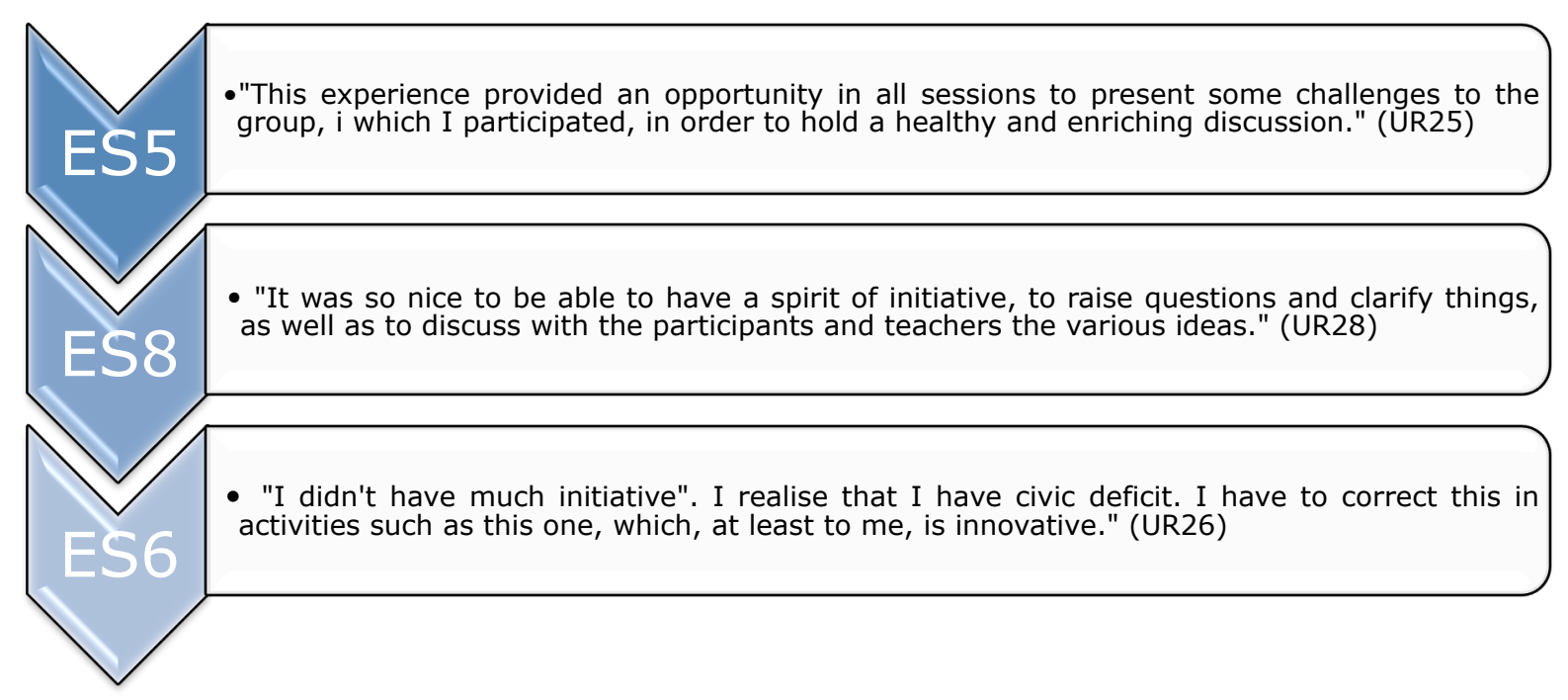

Figure. 4. Initiative in Learning.

Source: Authors.

As we can see in the first record, student -ES5- refers that the educational experience was enriching and allowed him/her to have initiative, giving the opportunity of challenging the group to make the discussions more stimulating.

Student -ES8-, in turn, and along the same line of thinking, highlights the fact that this environment gave him the opportunity to ask questions and have a spirit of initiative. This is interesting feedback that confirms one of the model's strengths - the Educational Experience of a Humanist Nature -, where students see themselves as active individuals, builders of their knowledge, engaging in and committing themselves to their learning process and integrated in a community, and teachers see themselves as moderators who guide the educational experience and foster positive human interaction. As student -ES7- states:

ES7- "(...) I always tried to answer the teacher's questions, tried to be proactive whenever I could, tried to share my points of view and assimilated interpretations with the rest of the group." (UR27)

As in the previously analysed dimension, in the third record not all students showed they had that spirit of initiative, for one reason or another. In the case of this specific student, and in his/her own words, this lack of initiative must be because he/she doesn't master the contents addressed in class, which the student refers to as a "civic deficit".

Student -ES9-, in turn, pinpoints another completely different factor external to the pedagogical setting, linked to the repressive environment of the prison, as we can see in the statement:

ES9- "I chose not to be too active because, despite the relaxed atmosphere in the sessions, it is always good to remember that this is a 
prison." (UR29)

Finally, and in respect of the third category, Autonomy in Learning, for which we also have twenty records, the classification of these records shows that opinions are in consonance, clearly indicating that, for students, the environment, methodology and teachers have given them the autonomy to manage their participation and share ideas and opinions. Some have highlighted the decisive role of teachers, in particular how they directed the discussions and encouraged participation, thus promoting a truly collaborative environment and space with the help of the audiovisual resources explored in class.

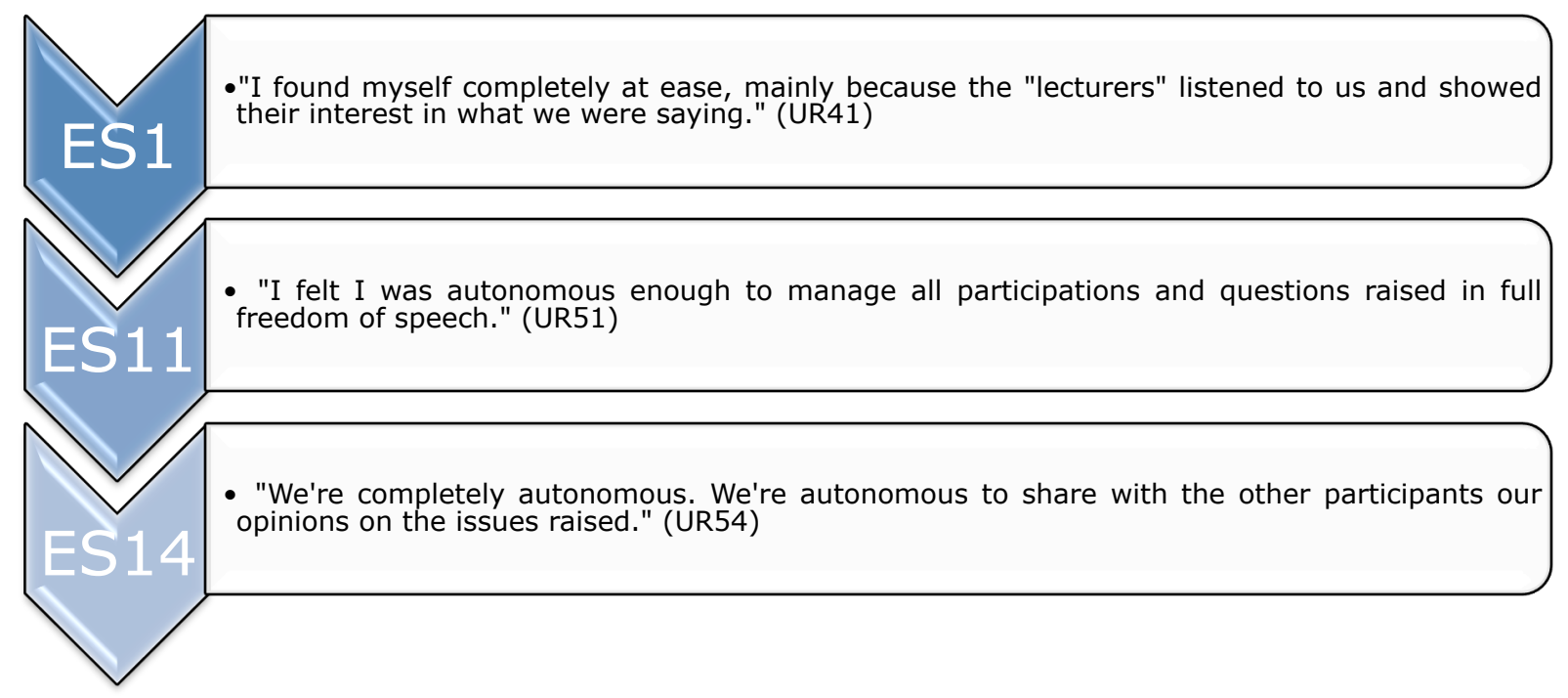

Figure. 5. Autonomy in Learning.

Source: Authors.

As we can see in the records below, these students refer that the "lecturers" allowed them to manage their own participation, there was room for "sharing of opinions", for being "at ease", for "freedom of speech" and "total" autonomy, as they put it.

There was also "responsibility", "respect" without "constraints", as shown below:

ES5- "When managing my participation, I always tried to participate in a responsible and attentive manner, where possible... Respecting the group so that everyone could share their ideas, so that they could analyse and discuss everyone else's ideas." (UR45)

ES6- "I felt no constraints on my autonomy. On the contrary, I was encouraged to be autonomous and to participate." (UR46)

\section{Conclusions}

Education is a universal right and plays an important role in human development, as it helps a person to build personality and character. Even when individuals are detained they have the same rights in accessing education. Being detained implies losing some rights but, where possible, these should not be extended to education, mainly because education and training, in this context, tends to be a promoter of social reintegration and a means to fight against repeat offences. 
This is the premise on which we sought to develop a Lifelong Learning (LLL) programme focused not only on the construction of responsible citizenship, but also on the development of learning skills related with the potential to learn and learning initiative and autonomy, transferable to the different contexts of detainment.

The main findings of the study have led to the conclusion that this educational environment anchored in an approached based on the principles of the pedagogical model developed by Moreira (2017) for the design of e-activities focused on the "deconstruction" moving images have had very positive effects on how most students perceive their learning skills. The negative perceptions found are more a matter of expressing public opinions half-heartedly and uneasily on some topics in "sensitive" environment such as prisons, than with the methodology developed.

From the analysis of the findings it may be concluded that, according to students, the educational/filmic space created is very dynamic and interactive, promotes the participation and acquisition of the learning skills under analysis: active learning, initiative and autonomy in learning. Also related thereto, recent studies also point to the educational potential of audiovisual and motion-picture language, both in the acquisition of scientific knowledge and in the development of psychological constructs, such as academic self-concept, reflected in cognitive and social abilities (Moreira, 2017; Almeida, 2017).

On a closing note, the use of audiovisual resources such as the cinema means that it is possible to envisage the pedagogical process differently, especially in places with the characteristics of a prison. However, change should not be seen only from a technological viewpoint, but also in pedagogical and cultural terms. Pressing "play" and seeing the moving images is not enough. These audiovisual resources should form part of an approach and model that fosters a learning vision based on the acquisition of contents and knowledge, but also on the development of learning skills. Several international studies, such as the Partnerships for the 21st Century Skills (P21) (https://www.21stcenturyskills.org), the study of the European Policy Network on Key Competences in School Education (KeyCoNet) (http://keyconet.eun.org/) or, as mentioned before, studies already developed in Spain (Ferrés, 2007; Ferrés \& Piscitelli, 2012), have highlighted common fields, such as Communication Competences - oral and written communication skills, literacy in technology and media; Critical Thinking and Problem-Solving Skills and Interpersonal and Self-Directed Competences - collaboration and team work, sensitivity and social responsibility, adaptation and flexibility, curiosity and creativity, and autonomy and initiative, the latter being analysed in this paper with greater emphasis.

With the perception of competences actually being an indicator of effectiveness, which to a certain measure corroborates the approaches and models focused on the development of competences, we have noted that the perception of the majority of students involved in this educational programme regarding the ability to learn actively and autonomously is rather positive.

As mentioned before, we hope that programmes such as these are able to address some of the challenges that the digital society poses to vulnerable groups, such as the prison population, whilst helping to ensure the right of access to education to which every citizen is entitled, in respect of the human rights of individuals deprived of their liberty or otherwise. 


\section{References}

Aguaded-Gómez, I., \& Pérez-Rodríguez, M. A. (2012). Strategies for media literacy: Audiovisual skills and the citizenship in Andalusia. New Approaches in Educational Research, 1(1), 22-26.

Almeida, R. (2017). Cinema e Educação: Fundamentos e Perspectivas [Cinema and Education: Fundaments and perspectives]. Educação em Revista, 33, 1-28.

Bardin L. (1977), L'analyse de contenu [Content analysis]. Paris: PUF.

Buckingham, D. (2009). The future of media literacy in the digital age: some challenges for policy and practice. In P. Verniers (Ed.), Media literacy in Europe: controversies, challenges and perspectives (pp. 13-24). Bruxelles: EuroMeduc.

Campos, S. (2015). Sistemas prisionais europeus [European Prisoner Systems]. (Unpublished master's thesis). Universidade Nova de Lisboa, Lisbon.

Carretero, S., Vuorikari, R., \& Punie, Y. (2017). DigComp 2.1: The Digital Competence Framework for Citizens with eight proficiency levels and examples of use. Luxembourg Publication Office of the European Union. Doi: $10.2760 / 38842$

Council of Europe (1989). Recomendação (89) [Recommendation of the Council of Europe on the rules of European prisons] 12, october 13.

European Commission (2003). Communication from the Commission to the Council, the European Parliament, the Economic and Social Committee and the Committee of the Regions - eEurope 2002 Final Report [COM (2003) 66 final]. Bruxels: Publication Service of the European Commission. Retrieved April 17, 2017: http://eur-lex.europa.eu/LexUriServ/LexUriServ.do?uri=CELEX:52003DC0066:EN:NOT

European Commission (2005). eEurope - An information society for all. Bruxels: Publication Service of the European Commission. Retrieved April 17, 2017: http://europa.eu/legislation_summaries/information_society/124221_pt.htm

European Parliament and the Council (2006). Recommendation of the European Parliament and of the Council of 18 December 2006 on key competences for lifelong learning. Official Journal of the European Union, L394/310.

European Parliament and the Council (2007). Directive 2007/65/CE.

European Union (2006). Competências essenciais para a aprendizagem ao longo da vida [Main skills for lifelong learning], 2006. Retrieved April 13, 2018: http://eur-lex.europa.eu/legal-content/PT/TXT/HT ML/?uri=URISERV:c11090\&from $=$ PT

Faria, L., Rurato, P., \& Lima Santos, N. (2000). Papel do auto-conceito de competência cognitiva e da autoaprendizagem em contexto sócio-laboral [The role of self-concept of cognitive competence and of selflearning in socio-working context]. Análise Psicológica, 2, 203-219.

Ferrés, J. (2007). La competencia en comunicación audiovisual: Dimensiones e indicadores [Competence in audiovisual communication: dimensions and indicators]. Comunicar, 29, XV, 100-107.

Ferrés, J., \& Piscitelli. A. (2012). La competencia mediática: Propuesta articulada de dimensiones e indicadores [Media competence: articulated proposal of dimensions and indicators]. Comunicar, 38, XIX, 75-82.

Fresquet, A. (2013), Cinema e Educação. Reflexões e experiências com professores e estudantes de educação básica, dentro e "fora" da escola [Cinema and education. Thoughts and experiences with teachers and students of low secondary education, in and "out" of school]. Belo Horizonte: Autêntica.

Garrison, D., \& Anderson, T. (2005). El e-learning en el siglo XXI. Investigación e práctica [e-learning in the $X X$ th century. Research and practice]. Barcelona: Octaedro.

Gutiérrez, A., \& Tyner, K. (2012). Media Literacy in Multiple Contexts. Comunicar, 38, 10-12. DOI: $10.3916 / C 38-2012-02-00$

Hernandez, F. (2000). Cultura visual, mudança educativa e projeto de trabalho [Visual culture, educational change and work project]. Porto Alegre: Artes Médicas Sul.

Lima Santos, N., Faria, L. \& Rurato, P. (2000). Educação e aprendizagem de adultos: Avaliação do autoconceito de competência cognitiva e da autoaprendizagem [Education and adult learning: evaluation of selfconcept of cognitive competence and self learning]. Revista Galego-Portuguesa de Psicoloxía e Educación, 6(4), 649-656.

Lima Santos, N., Rurato, P., \& Faria, L. (2000). Auto-aprendizagem e auto-conceito de competência em contexto empresarial [Self-learning and competence self-concept in corporate environment]. Psicologia: Teoria, Investigação e Prática, 1, 135-146.

Miles, M., \& Huberman, M. (1994) Drawing valid meaning from qualitative data: toward a shared craft. Educational Researcher, 13, 20-30.

Moreira, J. A. (2017). A pedagogical model to deconstruct moving pictures in virtual learning environments and its impact on the self-concept of postgraduate students. Journal of e-Learning and Knowledge 
Society,13 (1), 77-90. Retrieved from: http://www.je-lks.org/ojs/index.php/JeLKS_EN/article/view/1255. DOI: https://doi.org/10.20368/1971-8829/1255

Moreira, J. A., et al. (2016). Sistemas prisionais. História e desafios educacionais da era digital [Prison systems. History and educational challenges in the digital era]. Santo Tirso: Whitebooks.

National Council of Education (2011). Recomendação sobre Educação para a Literacia Mediática [Recommendation about education for media literacy], n. 6/2011.

Nyhan, B. (1996). Desenvolver a capacidade de aprendizagem das pessoas: Perspectivas europeias sobre a competência de auto-aprendizagem e mudança tecnológica [Developing the learning capacity of people: European perspectives on the competence of self-learning and technological change]. Caldas da Rainha: Eurotecnet.

Portugal INCoDe.2030 Iniciativa Nacional Competências Digitais e.2030 - Um programa integrado de competências digitais para Portugal, 2017-2030. Retrieved March 12, 2019: http://www.adcoesao.pt/content/iniciativa-nacional-competencias-digitais-e2030-portugal-incode2030

Preece, J. (2011). Research in adult education and lifelong learning in the era of CONFINTEA VI. International Journal of Lifelong Education, 30 (1), 99-117.

Rurato, P. (2008). As Características dos Aprendentes na Educação a Distância - Impacto no Processo Educativo com vista ao Desenvolvimento de Estratégias de Sucesso [The characteristics of learners in Distance Learning - impact on the educational process for developing success strategies] (Unpublished doctoral dissertation). Universidade de Aveiro, Aveiro.

Spiro, R., Vispoel, W., Schmitz, J., Samarapungavan, A., \& Boerger, A. (1987), Knowledge Aquisition for Application: Cognitive Flexibility and Transfer in Complex Content Domains, In B. Britton \& C. Glynn C. (eds.), Executive Control in Processes in Reading (p. 177-199), New Jersey: Lawrence Erlbaum Associates.

Spiro, R., Coulson, R., Feltovich, P., \& Anderson, D. (1988). Cognitive flexibility: Advanced knowledge acquisition ill-structured domains. Proc. of the Tenth Annual Conference of Cognitive Science Society. Hillsdale: Erlbaum, 375-383.

Unesco (2010). Relatório Global sobre Aprendizagem e Educação de Adultos [Global report on adult learning and education]. Brasília: Instituto da UNESCO para a Aprendizagem ao Longo da Vida (UIL).

Unesco (2013). Global Media and Information Literacy Assessment Framework: Country Readiness and Competencies. Paris: UNESCO.

Vala, J. A. (1986). Análise de conteúdo [Content analysis]. In A. Silva \& J. Pinto (eds.), Metodologia das Ciências Sociais [Methodology of social sciences]. Porto: Edições afrontamento.

Veiga Simão, A.M., \& Flores, A.M. (2006). O aluno universitário. Aprender a auto-regular a aprendizagem sustentada por dispositivos particiapativos [The university student. Learning to self-regulate learning supported by participatory devices]. Revista Ciências \& Letras, 40, 229-251.

Vuorikari, R., Punie, Y., Carretero Gomez, S., \& Van den Brande, G. (2016). Digcomp 2.0 the digital competence framework for citizens. Update phase 1: The Conceptual Reference Model. Luxembourg Publication Office of the European Union.

Wang, F., \& Hannafin, M. J. (2005), Design-based research and technology-enhanced learning environments, Educational Technology Research and Development, 53(4), 5-23.

Wilson, C., Grizzle, A., Tuazon, R., Akyempong, K., \& Cheung, C. K. (2011). Media and information literacy. Curriculum for teachers. Paris: UNESCO. 